1888.] Prafulla Chandra Ray on Copper-Magnesizum Group. 267

Monday, 2nd April 1888.

The Rev. Professor FLINT, D.D., Vice-President, in the Chair.

The following Communications were read :-

1. Analysis of the "Challenger" Meteorological Observations. By Dr Buchan.

2. On the Conjugated Sulphates of the Copper-Magnesium Group. By Prafulla Chandra Ray, Esq.

\title{
Historical and Introductory.
}

From time to time memoirs have appeared by various chemists, pointing out that there is a tendency among the sulphates of the magnesium group to combine with one another in definite molecular proportions. This tendency has been brought into connection with the fact that these sulphates have almost identical atomic volumes.

So early as the year 1840 Kopp drew attention to the fact that all the vitriolic sulphates have almost the same "atomic" volume (Ueber Atomvolum, Isomorphismus und specifischen Gewicht, Ann. xxxvi. p. 1, 1840).

Playfair and Joule (Chem. Soc. Jour., 121, 1848), Schiff, and, recently, Thorpe have confirmed and extended Kopp's classical work.

Schauffele found ("Ueber die mehrbasischen schwefelsauren Salze der Magnesiareihe," Jour. fiur Prakt. Chem., lv. 371, 1852) that when one sulphate of the magnesium group is dissolved to the point of saturation in a previonsly saturated solution of another, the crystals which are obtained contain the component sulphates in definite proportions.

In 1854 Rammelsberg published an elaborate paper on this subject. From the result of his researches he concluded that two sulphates of the copper-magnesium group often crystallise together in very simple ratios when they are dissolved together in equivalent proportions, the solution allowed to evaporate spontaneously, and the crystals collected fractionally as they are formed ("Ueber das Verhältniss in welchem isomorphe Körper zusammen krystallisiren und den Einfluss desselben auf die Form der Krystalle," Pogg. Ann., xci. 321). 